\title{
Algebraic Insights towards the Legal Transformation of Fault within in personam Defences under Modern Criminal Law
}

\author{
By Gabriel Hallevy*
}

In this paper, major aspects of the legal transformation of fault are examined due to algebraic insights. The transformation of fault deals with situations of entrance to mental states which exempt the offender from criminal liability. In these situations, the offender's mental state is transferred and transformed to the commission of the offense. This legal action resembles linear transformations in Algebra, and thus we can evaluate this legal structure more accurately due to algebraic insights.

Keywords: Mathematics and Law, General Defences, Transformation of Fault, actio libera in causa

\section{Introduction}

When a perpetrator voluntarily enters into a situation that requires an insanity, automatism, or intoxication defence to prevent imposition of criminal liability, applying one of these defences is not necessarily just. For example, if a person drinks alcohol deliberately and subsequently commits an offense, it is not right to exempt him from criminal liability based on the intoxication defence. Modern criminal law solves this problem by transforming the fault that existed at the time when the perpetrator placed him in a situation that removed his control to the time of the commission of the offense. This is the legal transformation of fault.

\section{The Legal Transformation of Fault}

\section{Basic Structure and Rationale}

When an offender commits an offense in a state of insanity, infancy, automatism, or intoxication, the fault itself cannot be consolidated. These states are presumed to prevent the consolidation of fault because they negate the offender's cognitive or volitive capabilities. Because fault is required for the imposition of criminal liability, if the offender has not consolidated it, no criminal liability can be imposed. The legal consequences of adopting such an

\footnotetext{
* Professor of Law, Faculty of Law, Ono Academic College. I thank the editors of the Athens Journal of Law for inviting me to contribute to the journal. For broader aspects of this idea see Hallevy G. (2015), The Matrix of Insanity in Modern Criminal Law (Springer).
} 
attitude ex ante would be catastrophic in social terms. Quite probably, potential offenders would deliberately bring themselves to one of the above situations, most likely intoxication, and plead not guilty.

Knowing that if the offense is committed in one of these states prevents imposition of criminal liability, potential offenders would simply commit it in one of these states. Traditionally, fault is examined at the time the offense has been committed (the time when the conduct has been consolidated). ${ }^{1}$ But in these situations it would be right to consider that the fault was consolidated when the offender entered the relevant state.

Indeed, it would be right to do so in all cases, if doing so is relevant to the factual or legal questions raised at a given trial. Considering the fault at the time when the offender entered the relevant state moves the time when the fault is examined from the time of the commission of the offense to an earlier time. Nevertheless, in order to impose criminal liability, an adequate fault must still be present at the time when the offense was committed. Therefore, the legal action does not end with the examination of the fault at an earlier point of time, but also involves copying the fault to the later point (the time of the commission of the offense).

This legal action is the transformation of fault. The legal function consists of examining the fault at one point in time and copying it to another point. What is being copied, however, is not the initial fault but a transformation of it. At the first point in time, the object of the fault consists of the entrance into the state of irresponsibility; at the second point in time, the object concerns the facts that form the factual element requirement of the offense at hand. Therefore, the legal function involves not merely the copying of the fault but also its transformation.

For example, A wants to kill B. While fully sober, A deliberately drinks alcohol to achieve the desired mental state for killing B. Shortly thereafter, A kills $\mathrm{B}$ in a state of intoxication and pleads not guilty. To impose criminal liability on A, it is necessary to prove A's fault in the offense. The fault consists of a combination of cognitive and volitive components in relation to the factual elements of the offense (homicide), and the offender argues that at the time when the offense was committed, i.e., when the conduct was consolidated $\left(\mathrm{t}_{2}\right)$, the required fault could not be consolidated and therefore no criminal liability can be imposed.

\footnotetext{
${ }^{1}$ Fowler v. Padget, (1798) 7 T.R. 509, 101 Eng. Rep. 1103; Thabo Meli, [1954] 1 All E.R. 373, [1954] 1 W.L.R. 228; Church, [1966] 1 Q.B. 59, [1965] 2 All E.R. 72, [1965] 2 W.L.R. 1220, 49 Cr. App. Rep. 206, 129 J.P. 366; Le Brun, [1992] Q.B. 61; Masilela, 1968 (2) S.A. 558 (A.D.); Ramsay, [1967] N.Z.L.R. 1005; Jackson v. Commonwealth, 100 Ky. 239, 38 S.W. 422 (1896); Masilela, 1968 (2) S.A. 558 (A.D.); Chiswibo, 1960 (2) S.A. 714; Scott, [1967] V.R. 276; Fagan v. Metropolitan Police Commissioner, [1969] 1 Q.B. 439, [1968] 3 All E.R. 442, [1968] 3 W.L.R. 1120, 52 Cr. App. Rep. 700, 133 J.P. 16; Miller, [1983] 2 A.C. 161, [1983] 1 All E.R. 978, [1983] 2 W.L.R. 539, 77 Cr. App. Rep. 17; Singh, [1974] 1 All E.R. 26, [1973] 1 W.L.R. 1444, 138 J.P. 85; Kaitamaki, [1985] 1 A.C. 147, [1984] 2 All E.R. 435, [1984] 3 W.L.R. 137, [1984] Crim. L.R. 564, 79 Cr. App. Rep. 251; Matthews, [1950] 1 All E.R. 137, 48 L.G.R. 190, 66 T.L.R. (Pt. 1) 153, 114 J.P. 73, 34 Cr. App. Rep. 55; People v. Decina, 2 N.Y.2d 133, 138 N.E.2d 799, 157 N.Y.S.2d 558 (1956); Hill v. Baxter, [1958] 1 Q.B. 277, [1958] 1 All E.R. 193, [1958] 2 W.L.R. 76, 56 L.G.R. 117, 42 Cr. App. Rep. 51.
} 
But if the court examines the situation at an earlier and yet relevant point of time, the offender is not as innocent as he would like to appear. When the offender has entered the state of intoxication $\left(t_{1}\right)$, the cognitive and volitive components were consolidated in the offender's mind. Two problems arise, however:

(1)the time of consolidation is earlier than the time of the commission of the offense; and

(2)the object of the cognitive and volitive components is not identical with the factual element components.

Both problems find their solution within the transformation of fault.

One of the functions of the transformation of fault has to do with the time axis, as the fault is being transferred from the point when the offender entered the fault-negating state $\left(t_{1}\right)$ to the point of the commission of the offense $\left(t_{2}\right)$. The assumption behind this transfer is that the fault-negating state (e.g., intoxication) preserves the offender's accountability for the commission of the offense, so that even if the offender could not have exercised control over the commission of the offense, he controlled the conditions under which the offense was committed and of the way in which it was committed.

For example, if the offender committed homicide while drunk, when the offense was committed $\left(\mathrm{t}_{2}\right)$ the offender had no control over his conduct, but he did control the conditions for entering into a state of intoxication and he consumed the alcohol voluntarily. When a person consumes alcohol voluntarily, he remains accountable for all consequences of the intoxication. Thus, the function of the transformation of fault is to transfer the fault from the point when the offender entered a state of irresponsibility to the point of the commission of the offense.

Another function of the transformation of fault is the substantive change in the object of the fault. The required fault in the case of the commission of the offense, as part of the mental element requirement, relates to the components of the factual element in a symmetric structure. For example, it is necessary to prove awareness of conduct, of circumstances, etc. General awareness has no meaning in criminal law; awareness must relate to a particular object, i.e., the components of the factual element.

In addition to transferring the fault from one point in time to another, its object in both points of time must be identical. But awareness of drinking alcohol does not parallel awareness of stealing. Therefore, for the transformation of fault to be complete, the object of the fault must be metamorphosed so that it matches the mental element requirement. But how can fault in relation to object $\mathrm{A}$ be transformed into fault in relation to object $\mathrm{B}$ ?

This type of change, however, is not rare in criminal law. All presumptions of the mental element requirement are based on such a transformation, the most significant one in this context being the presumption of transferred malice (error in persona, error in objecto), which transfers intent in relation to one 
object to another. ${ }^{1}$ This is not the only instance. The presumption of indirect intent transfers awareness of the probability that the results would occur to purpose (specific intent) in relation to the results themselves. ${ }^{2}$

Thus, the change of object that takes place in the course of the transformation of fault is not exceptional in criminal law; nevertheless, it must be justified because a legal structure should reflect a just premise. The rationale of the change in object relates to the inherent connection between these objects. The commission of the offense, and therefore the components of its factual element, is held to be the consequence of the fault-negating state. Therefore, if the offender had not been intoxicated, no offense would have been committed, and if the offender had not entered this state, the offense would not have been committed.

The same rationale characterizes the mental element presumptions. For example, concerning the transferred malice presumption: if the offender had not intended to commit an offence against $A$, no offence would have been committed against B. Thus, the change of object together with the transfer in time forms the transformation of fault.

The European-Continental doctrine of actio libera in causa, discussed above, is an early conceptualization of the idea of transformation of fault. Originally, it referred to two basic types of fault when entering the relevant state: general intent and specific intent. Although actio libera is the "prototype" of the transformation of fault function, it is partial because it does not cover all possible types of fault. For example, if the offender entered the relevant state in a case of negligence, the actio libera would not be relevant. A comprehensive function could be based on the actio libera understandings, but they would have to be widened to cover every type of fault.

The derivative functional questions are when the transformation of fault should be activated and what its consequences are. These questions are discussed below with respect to infancy, automatism, intoxication, and insanity.

\footnotetext{
${ }^{1}$ Salisbury, (1553) 1 Plowd. 100, 75 Eng. Rep. 158; Saunders, (1576) 2 Plowd. 473, 75 Eng. Rep. 706; Gore, (1611) 9 Co. Rep. 81a, 77 Eng. Rep. 853; Jarvis, (1837) 2 Mood. 40, 174 Eng. Rep. 207; Michael, (1840) 2 Mood. 120, 169 Eng. Rep. 48; Hussain, [1969] 2 Q.B. 567, [1969] 2 All E.R. 1117, [1969] 3 W.L.R. 134, 53 Cr. App. Rep. 448; Mitchell, [1983] 1 Q.B. 741, [1983] 2 All E.R. 427, [1983] 1 W.L.R. 938, 76 Cr. App. Rep. 293; Ford v. State, 330 Md. 682, 625 A.2d 984 (1993); State v. Brady, 745 So.2d 954 (Fla.1999); Mayweather v. State, 29 Ariz. 460, 242 P. 864 (1926); Coston v. State, 144 Fla. 676, 198 So. 467 (1940); Gladden v. State, 273 Md. 383, 330 A.2d 176 (1974); State v. Martin, 119 N.J. 2, 573 A.2d 1359 (1990); State v. Henry, 253 Conn. 354, 752 A.2d 40 (2000); People v. Sanchez, 26 Cal.4th 834, 111 Cal.Rptr.2d 129, 29 P.3d 209 (2001); United States v. Fornez-Espinoza, 241 Fed. Appx. 398 (2007); RG 2, 335; RG 3, 384; RG 54, 349; RG 58, 27; RG 67, 258; BGH 9, 240; BGH 14, 193; BGH 34, 53.

${ }^{2}$ Director of Public Prosecutions v. Morgan, [1976] A.C. 182, [1975] 2 All E.R. 347, [1975] 2 W.L.R. 913, 61 Cr. App. Rep. 136, 139 J.P. 476; Heard, [2007] E.W.C.A. Crim. 125, [2008] Q.B. 43, [2007] 3 All E.R. 306; B., [2008] E.W.C.A. Crim. 4, [2008] All E.R. (D) 85; State v. Clardy, 73 S.C. 340, 53 S.E. 493 (1906); People v. Campbell, 237 Mich. 424, 212 N.W. 97 (1927); United States v. Kabat, 797 F.2d 580 (8th Cir.1986).
} 


\section{Algebraic Insights}

The fascinating field of mathematics and law should be explored more thoroughly, especially with a view toward possible applications in mechanizing or computing portions of the law. Mathematical principles can be implemented within the law in order to clarify certain legal principles and reduce the probability of error. At times, legal principles are formulated by induction in ways that are over inclusive or under inclusive. When these principles are reformulated in mathematical terms, the legal realm becomes wider, clearer, and quite likely more just.

Transformation of fault resembles linear transformation functions, one of the basic instruments in linear algebra. Because transformation of fault relates to fault, we can define the linear space as the space of fault. Therefore, the basis would include the relevant states that span the space: specific intent $\left(\mathrm{v}_{1}\right)$, general intent $\left(\mathrm{v}_{2}\right)$, negligence $\left(\mathrm{v}_{3}\right)$, and strict liability $\left(\mathrm{v}_{4}\right)$. When the offender has no fault at all, the element of the space is null ( $\underline{0})$.

The transformation of fault acts as a linear transformation. For example, A had general intent $\left(\mathrm{v}_{2}\right)$ with regard to drinking alcohol, and negligence $\left(\mathrm{v}_{3}\right)$ with regard to not taking the medication he uses to control his involuntary reflexes. Therefore:

$$
\mathrm{T}\left(\mathrm{v}_{2}+\mathrm{v}_{3}\right)=\mathrm{T}\left(\mathrm{v}_{2}\right)+\mathrm{T}\left(\mathrm{v}_{3}\right)
$$

This means that general intent would be considered with regard to the offense committed under intoxication, and negligence with regard to the offense committed under automatism.

Moreover, A had $\lambda$ general intents $\left(\mathrm{v}_{2}\right)$ with regard to the $\lambda$ glasses of alcohol consumed on different occasions. Therefore:

$$
\mathrm{T}\left(\lambda \mathrm{v}_{2}\right)=\lambda \mathrm{T}\left(\mathrm{v}_{2}\right)
$$

This means general intent would be considered for each time the offender offended in a state of intoxication.

If the offender had no fault at the time he entered the relevant state (e.g., involuntary intoxication), no fault is related to the factual element components. Therefore:

$$
\mathrm{T}(\underline{0})=\underline{0}
$$

A full and accurate transformation of fault (T) would produce an isomorphism. Thus, for each $v_{i}$ there is a different image $T v_{i}$, so that the kernel is $\underline{0}$ and nothing but it. Therefore, if:

$$
\operatorname{dimkerT}+\operatorname{dim} \operatorname{Im} \mathrm{T}=\mathrm{n}
$$


and $:^{1}$

$$
\operatorname{kerT}=\underline{0}
$$

then:

ImT spans the fault space ( $\operatorname{dim} \operatorname{Im} \mathrm{T}=\mathrm{n}$, and $\mathrm{T}$ is a surjective function), the null space is $\underline{0}$ ( $\mathrm{T}$ is an injective function), and $\mathrm{T}$ forms an isomorphism. Isomorphism is important because it refers to the legal legitimacy of the transformation of fault. Only if the definition of the transformation of fault forms an isomorphism (no over-inclusions or under-inclusions are possible) is the criminal law just both toward the offender and toward society. Unfortunately, transformations of fault do not produce isomorphism in all legal systems, which can be over-inclusive (e.g., negligence leading to automatism becomes general intent for the factual element components) or under-inclusive (e.g., negligence leading to intoxication becomes no-fault with regard to the factual element components).

If the legal provisions that form the transformation of fault fail to produce an isomorphism, the algebraic insights described above can suggest ways of correcting and improving criminal law to make it more just.

\section{Applicability within in Personam General Defences in Criminal Law}

The transformation of fault may be applicable to all controllable in personam states. $^{2}$

\section{Infancy Defence}

Infancy may refer to both biological and mental age. Unless the offender has found the way of entering a state of infancy by becoming younger or mentally retarded, transformation of fault is irrelevant in this case. As long as one cannot control entering a state of infancy, transformation of fault is not applicable.

This is only one situation of transformation of fault, which refers to the transformation of the offender's "no fault" in entering the state of infancy (by being born as such) to the factual element components of the offense committed when infant. The result is identical whether or not the transformation of fault function is activated in infancy, but its activation is significant as it makes this function be considered general. If there is a way to control mental retardation by any means, the transformation of "no fault" would not be the only transformation within this function.

\footnotetext{
${ }^{1}$ The dimension of the kernel and the dimension of the image of the linear transformation are equal together to the dimension of the space of which the transformation acts.

${ }^{2}$ Not only in these defenses, but the other defenses (in rem defenses) exceeds from the theme of this article.
} 


\section{Automatism Defence}

One of the elements of the presumption of automatism is inability to control the conditions that led to the inability to control one's bodily movements. This element refers to the transformation of fault. According to the original concept of actio libera in causa, if the offender's conduct was not coerced, the automatism defence is not applicable. ${ }^{1}$ Therefore, if the state of automatism was controllable, and if the offender controlled his entry into this state, he is not considered having been coerced and the delinquent conduct reflects the fault. Automatism that can be controlled, however, is not necessarily associated with a given purpose to commit and offense.

Inclusion of this element within the transformation of fault function requires us to distinguish between five types of fault:

(1)specific intent to enter into a state of automatism (the offender entered the state of automatism deliberately in order to commit the offense);

(2)general intent to enter into a state of automatism (the offender entered the state of automatism being fully aware of what he was doing and/or through recklessness);

(3)negligence in entering the state of automatism;

(4)strict liability in entering the state of automatism; and

(5)no fault in entering the state of automatism.

Application of the transformation of fault function to these five types of fault, transforms, in each case, the fault from the point when the offender entered the state of automatism to the time when he committed the offense, although when he committed the offense his conduct contained no fault. Applicability of this function as part of the automatism defence can be illustrated by an example that can be divided into five different scenarios, based on the five types of fault.

Consider the case of a driver who causes the death of a person in a car accident. The investigation reveals that the offender had fainted while driving and lost control over the vehicle, after which the car struck the victim, causing his death. In this example, the first element of the presumption of automatism is consolidated because the offender had no control over his bodily movements. Investigation of the reasons for the fainting, however, may produce five different results, based on the following scenarios:

(1)This was not the first time the driver has fainted while driving. The driver was aware of his condition, and knew that lack of sleep would have such an effect on him. The driver deliberately avoided sleeping the night before so that he would faint exactly at the time and place required to kill the victim, by losing control over his car;

\footnotetext{
${ }^{1}$ Government of the Virgin Islands v. Smith, 278 F.2d 169 (3rd Cir.1960); People v. Freeman, 61 Cal.App.2d 110, 142 P.2d 435 (1943); State v. Hinkle, 200 W.Va. 280, 489 S.E.2d 257 (1996). For intoxication see in Sheehan, [1975] 2 All E.R. 960, [1975] 1 W.L.R. 739, 60 Cr. App. Rep. 308; Menniss, [1973] 2 N.S.W.L.R. 113; Kamipeli, [1975] 2 N.Z.L.R. 610.
} 
(2)This was not the first time the driver has fainted while driving. The driver was aware of his condition, but hoped that this time it would not happen, or he was indifferent to this possibility;

(3)This was the first time the driver fainted while driving a car, but a few days earlier was diagnosed with a disease, one of symptoms of which was fainting. A reasonable person would have asked the physicians about the symptoms of his disease, but the offender did not;

(4)This was the first time the driver fainted while driving a car, but the offender did not take all reasonable measures to prevent the fainting, e.g. eating and drinking in the past 24 hours;

(5)This was the first time the driver fainted while driving a car and nothing could have prevented it.

Each of the five scenarios matches a different legal situation regarding criminal liability for homicide, and this is an isomorphic match.

Scenario (1) refers to specific intent in entering into the state of automatism. Transformation of this type of fault from the time the offender entered the state of automatism to the point of the commission of the offense combines the factual element of homicide (causing a person's death) with specific intent. Thus, although at the moment the homicide was committed, no fault accompanied the offense, the homicide is considered to have been committed with specific intent. In most legal systems this refers to murder.

Scenario (2) refers to general intent in entering into the state of automatism. Transformation of this type of fault from the time the offender entered the state of automatism to the point of the commission of the offense combines the factual element of homicide (causing a person's death) with general intent. Thus, although at the moment the homicide was committed, no fault accompanied the offense, the homicide is considered to have been committed with general intent. In most legal systems this refers to manslaughter.

Scenario (3) refers to negligence in entering into the state of automatism. Transformation of this type of fault from the time the offender entered the state of automatism to the point of the commission of the offense combines the factual element of homicide (causing a person's death) with negligence. Thus, although at the moment the homicide was committed, no fault accompanied the offense, the homicide is considered to have been committed with negligence. In most legal systems this refers to negligent homicide.

Scenario (4) refers to strict liability in entering into the state of automatism. Transformation of this type of fault from the time the offender entered the state of automatism to the point of the commission of the offense combines the factual element of homicide (causing a person's death) with strict liability. Thus, although at the moment the homicide was committed, no fault accompanied the offense, the homicide is considered to have been committed with strict liability. In some legal systems this refers to felony murder.

Scenario (5) refers to no fault in entering into the state of automatism. This is the basic situation for no imposition of criminal liability on the offender. 
Transformation of this type of fault from the time the offender entered the state of automatism to the point of the commission of the offense combines the factual element of homicide (causing a person's death) with no fault. Thus, without the required fault, no criminal liability may be imposed on the offender.

In all of the above scenarios, the pattern of transformation of fault is identical, the only difference between them being the type of fault being transformed. Thus, the same fault that was present when the offender entered the state of automatism is being transferred to the point when the offense was committed, and it refers the factual element components of the offense. This function enables criminal law to override and overcome the absence of fault during the actual commission of the offense, and therefore modern criminal law has embraced the concept. ${ }^{1}$

\section{Intoxication Defence}

Consider the case of a driver who causes the death of a person in a car accident. The investigation reveals that the offender was drunk while driving and lost control over the car, after which the car struck the victim, causing his death. In this example, all the elements of the presumption of intoxication are consolidated, but investigation of the reasons for the intoxication may produce five different results, based on the following scenarios:

(1)The offender went to a bar with some friends before the accident and drank three glasses of alcohol deliberately, intending to kill the victim. The drinking eased the offender's mind making it easier for him to commit the offense;

(2)The offender went to a bar with some friends before the accident and drank a few glasses of alcohol. He was aware of the alcoholic content of the drinks, but hoped that it would not affect his driving, or was indifferent as to that possibility;

(3)The offender went to a bar with some friends and ordered a drink. Although the offender was not aware of the alcoholic content of his drink, any reasonable person in these circumstances would have known about it;

(4)The offender drank something before driving, but was not aware of its alcoholic content, and no reasonable person could have known about it under the same circumstances. Nevertheless, the offender did not take all reasonable measures to prevent the error;

(5)The offender had just been released from the hospital, where an alcoholic substance was erroneously was injected into his blood. The medical staff had told him that it was safe for him to drive.

\footnotetext{
${ }^{1}$ RG 60, 29; RG 73, 177; VRS 23, 212; VRS 46, 440; VRS 61, 339; VRS 64, 189; DAR 1985, 387; BGH 2, 14; BGH 17, 259; BGH 21, 381; RG 22, 413; VRS 23, 213; VRS 25, 33; DAR 1983, 395; Jescheck H.H. und Weigend T. (5 Auf., 1996), Lehrbuch des Strafrechts Allgemeiner Teil, 445-448.
} 
Each of the five scenarios matches a different legal situation regarding criminal liability for homicide, and this is an isomorphic match.

Scenario (1) refers to specific intent in entering into the state of intoxication. Transformation of this type of fault from the time the offender entered the state of intoxication to the point of the commission of the offense combines the factual element of homicide (causing a person's death) with specific intent. Thus, although at the moment the homicide was committed, no fault accompanied the offense, the homicide is considered to have been committed with specific intent. In most legal systems this refers to murder. ${ }^{1}$

Scenario (2) refers to general intent in entering into the state of intoxication. Transformation of this type of fault from the time the offender entered the state of intoxication to the point of the commission of the offense combines the factual element of homicide (causing a person's death) with general intent. Thus, although at the moment the homicide was committed, no fault accompanied the offense, the homicide is considered to have been committed with general intent. In most legal systems this refers to manslaughter. $^{2}$

Scenario (3) refers to negligence in entering into the state of intoxication. Transformation of this type of fault from the time the offender entered the state of intoxication to the point of the commission of the offense combines the factual element of homicide (causing a person's death) with negligence. Thus, although at the moment the homicide was committed, no fault accompanied the offense, the homicide is considered to have been committed with negligence. In most legal systems this refers to negligent homicide. ${ }^{3}$

\footnotetext{
${ }^{1}$ Kingston, [1995] 2 A.C. 355, [1994] 3 All E.R. 353, [1994] 3 W.L.R. 519, [1994] Crim. L.R. 846, 99 Cr. App. Rep. 286, 158 J.P. 717; Gallagher, [1963] A.C. 349, [1961] 3 All E.R. 299, [1961] 3 W.L.R. 619, 45 Cr. App. Rep. 316; McDaniel v. State, 356 So.2d 1151 (Miss.1978); State v. Richardson, 495 S.W.2d 435 (Mo.1973); State v. Shipman, 354 Mo. 265, 189 S.W.2d 273 (1945); State v. Stasio, 78 N.J. 467, 396 A.2d 1129 (1979); State v. Vaughn, 268 S.C. 119, 232 S.E.2d 328 (1977); Chittum v. Commonwealth, 211 Va. 12, 174 S.E.2d 779 (1970).

${ }^{2}$ Hopt v. People, 104 U.S. 631, 26 L.Ed. 873 (1881); Occhicone v. State, 768 So.2d 1037 (Fla.2000); Aszman v. State, 123 Ind. 347, 24 N.E. 123 (1890); State v. Wilson, 234 Iowa 60, 11 N.W.2d 737 (1943); Heideman v. United States, 259 F.2d 943 (D.C.Cir.1958); Jamison v. State, 53 Okl.Crim. 59, 7 P.2d 171 (1932); Allen v. United States, 239 F.2d 172 (6th Cir.1956); People v. Jones, 263 Ill. 564, 105 N.E. 744 (1914); People v. Eggleston, 186 Mich. 510, 152 N.W. 944 (1915); People v. Guillett, 342 Mich. 1, 69 N.W.2d 140 (1955); Roberts v. People, 19 Mich. 401 (1870); State v. Watts, 223 N.W.2d 234 (Iowa 1974); Commonwealth v. Kichline, 468 Pa. 265, 361 A.2d 282 והשוו (1976),Walden v. State, 178 Tenn. 71, 156 S.W.2d 385 (1941); People v. Freedman, 4 Ill.2d 414, 123 N.E.2d 317 (1954); State v. Huey, 14 Wash.2d 387, 128 P.2d 314 (1942); State v. Shine, 193 Conn. 632, 479 A.2d 218 (1984); Brown v. Commonwealth, 575 S.W.2d 451 (Ky.1978); People v. Townsend, 214 Mich. 267, 183 N.W. 177 (1921); People v. Register, 60 N.Y.2d 270, 469 N.Y.S.2d 599, 457 N.E.2d 704 (1983); State v. Trott, 190 N.C. 674, 130 S.E. 627 (1925); Edwards v. State, 202 Tenn. 393, 304 S.W.2d 500 (1957); People v. Decina, 2 N.Y.2d 133, 157 N.Y.S.2d 558, 138 N.E.2d 799 (1956).

${ }^{3}$ People v. Garcia, 250 Cal.App.2d 15, 58 Cal.Rptr. 186 (1967); State v. Coates, 107 Wash.2d 882, 735 P.2d 64 (1987); People v. Whitfield, 7 Cal.4th 437, 27 Cal.Rptr.2d 858, 868 P.2d 272 (1994); State v. Brown, 122 N.M. 724, 931 P.2d 69 (1996); Stenzel v. United States, 261 Fed. 161 (8th Cir.1919); State v. Galvin, 147 Vt. 215, 514 A.2d 705 (1986); Embry v. State, 310 P.2d 617 (Okl.Crim.App.1957); State v. Campos, 122 N.M. 148, 921 P.2d 1266 (1996).
} 
Scenario (4) refers to strict liability in entering into the state of intoxication. Transformation of this type of fault from the time the offender entered the state of intoxication to the point of the commission of the offense combines the factual element of homicide (causing a person's death) with strict liability. Thus, although at the moment the homicide was committed, no fault accompanied the offense, the homicide is considered to have been committed with strict liability. In some legal systems this refers to felony murder. ${ }^{1}$

Scenario (5) refers to no fault in entering into the state of intoxication. This is the basic situation for no imposition of criminal liability on the offender. Transformation of this type of fault from the time the offender entered the state of intoxication to the point of the commission of the offense combines the factual element of homicide (causing a person's death) with no fault. Thus, without the required fault, no criminal liability may be imposed on the offender. $^{2}$

In all of the above scenarios, the pattern of transformation of fault is identical, the only difference between them being the type of fault being transformed. Thus, the same fault that was present when the offender entered the state of intoxication is being transferred to the point when the offense was committed, and it refers the factual element components of the offense. This function enables criminal law to override and overcome the absence of fault during the actual commission of the offense, and therefore modern criminal law has embraced the concept.

\section{Insanity Defence}

A person suffers from psychotic episodes, in the course of which he loses control over his physical motions. To retain his mental balance, he is instructed to take a certain medication every day at certain time. He knows that if he fails to do so he will lose self-control within a few hours. Under the influence of the medication he is fully aware of his motions and capable of controlling them. When his business competitor irritates him, he decides to kill him.

With full awareness of his act, he chooses not to take the medication, intending to kill his competitor. When he sees his competitor again, he is having a psychotic episode and kills him. He is charged with murder, and pleads the insanity defence. More generally, in practice, five different situations are possible:

\footnotetext{
${ }^{1}$ People v. Koerber, 244 N.Y. 147, 155 N.E. 79 (1926); Director of Public Prosecutions v. Beard, [1920] All E.R. Rep. 21, [1920] A.C. 479, 89 L.J.K.B. 437, 122 L.T. 625, 84 J.P. 129, 36 T.L.R. 379, 64 Sol. Jo. 340, 26 Cox C.C. 573, 14 Cr. App. Rep. 159.

${ }^{2}$ People v. Scott, 146 Cal.App.3d 823, 194 Cal.Rptr. 633 (1983); Torres v. State, 585 S.W.2d 746 (Tex.Crim.App.1979); Burrows v. State, 38 Ariz. 99, 297 P. 1029 (1931); Borland v. State, 158 Ark. 37, 249 S.W. 591 (1923); McCook v. State, 91 Ga. 740, 17 S.E. 1019 (1893); State v. Sopher, 70 Iowa 494, 30 N.W. 917 (1886); Perryman v. State, 12 Okl.Cr. 500, 159 P. 937 (1916); Brancaccio v. State, 698 So.2d 597 (Fla.App.1997); Prather v. Commonwealth, 215 Ky. 714, 287 S.W. 559 (1926); City of Minneapolis v. Altimus, 306 Minn. 462, 238 N.W.2d 851 (1976); State v. Gardner, 230 Wis.2d 32, 601 N.W.2d 670 (App.1999); Johnson v. Commonwealth, 135 Va. 524, 115 S.E. 673 (1923); Kane v. United States, 399 F.2d 730 (9th Cir.1968); State v. Sette, 259 N.J.Super. 156, 611 A.2d 1129 (1992); Tiffany L.P., Patological Intoxication and the Model Penal Code, 69 NEB. L. REV. 763 (1990).
} 
(1)The offender deliberately does not take the medication in order to kill the victim (purpose, or specific intent);

(2)The offender does not take the medication, but unreasonably hopes the psychotic episode will not take place (recklessness);

(3)The offender forgets to take the medication, although any reasonable person would not have forgotten to do so (negligence);

(4)The offender forgets to take the medication, and no reasonable person would have remembered to take it under the specific circumstances, but the offender did not take all reasonable measures required to remember taking the medication (strict liability); and-

(5)The offender is prevented from taking the medication (absence of fault).

In each of these five situations the offender kills the victim in the throes of a psychotic event. Does criminal law really address the problem in all five cases?

Although the immediate cause for the homicide is a psychotic episode, that episode can be fully controlled by taking the medication. If the psychotic episode is the result of not taking the medication, the situation may easily be referred to either intoxication or automatism. If it was the absence of the active ingredient of the medication that prevented the offender from controlling his conduct, the case definitely matches the defence of intoxication, and therefore the transformation of fault function related to intoxication may be activated.

Furthermore, if the psychotic episode can be characterized by uncontrollable bodily movements, and if the offender had control over entering into this state, the case definitely matches the defence of automatism as well, and therefore the transformation of fault function related to intoxication may again be activated. But if the situation is classified as pure insanity, no transformation of fault function is available, resulting in exemption from criminal liability. Thus, if the offender deliberately does not take his medication for mental balance, after which he commits an offense, no criminal liability can be imposed, as long as the insanity classification applies.

The rationale behind this legal outcome has to do with the social understanding of insanity as an uncontrollable situation, similar to infancy. The roots of this understanding are religious, as insanity was believed to be divine punishment or the result of some other divine act. Therefore, if the unfortunate person thus afflicted cannot control his condition, transformation of fault is irrelevant. But even despite these religious convictions, at least in some cases the offender was believed to deliberately enter into a state of insanity by sinning, so that transformation of fault could not have been entirely irrelevant.

When insanity was freed from its religious connotations, individuals learned how to control their mental deficiencies and their symptoms, with or without medication (e.g., through self-training). This brought insanity closer to automatism and intoxication, and distanced it from infancy. Indeed, in many situations individuals have the capability to control mental disorders, which raises again the question of the extent to which transformation of fault refers to insanity. 
This question also brings us back to that of the accurate demarcation between insanity, automatism, and intoxication. The answer to this question may be quite simple. If insanity is understood in current criminal law as uncontrollable, whenever the circumstances of the case indicate that it was controllable, the insanity defence is not applicable; the applicable defences may be intoxication or automatism.

In relation to the transformation of fault, it is irrelevant whether the defence that applies is intoxication or automatism because in both cases the transformation of fault is triggered. In legal systems that adopted different transformation of fault functions for intoxication and automatism, the distinction between intoxication and automatism may be and the correct function activated.

Thus, only when the relevant symptoms of insanity, if indeed they are related to insanity, are in practice beyond control, is the insanity defence applicable without triggering the transformation of fault. The test for controlling the symptoms is, naturally, based on the circumstances of the case. For example, if the offender is medicated and mentally balanced, it may not be easy to apply the insanity defence, but if the offender became aware of his mental disorder for the first time when offense was committed, the insanity defence is more likely to be applicable. A second episode of the symptoms of his mental deficiency, however, would probably not be considered insanity but intoxication or automatism after the offender has received treatment. 
